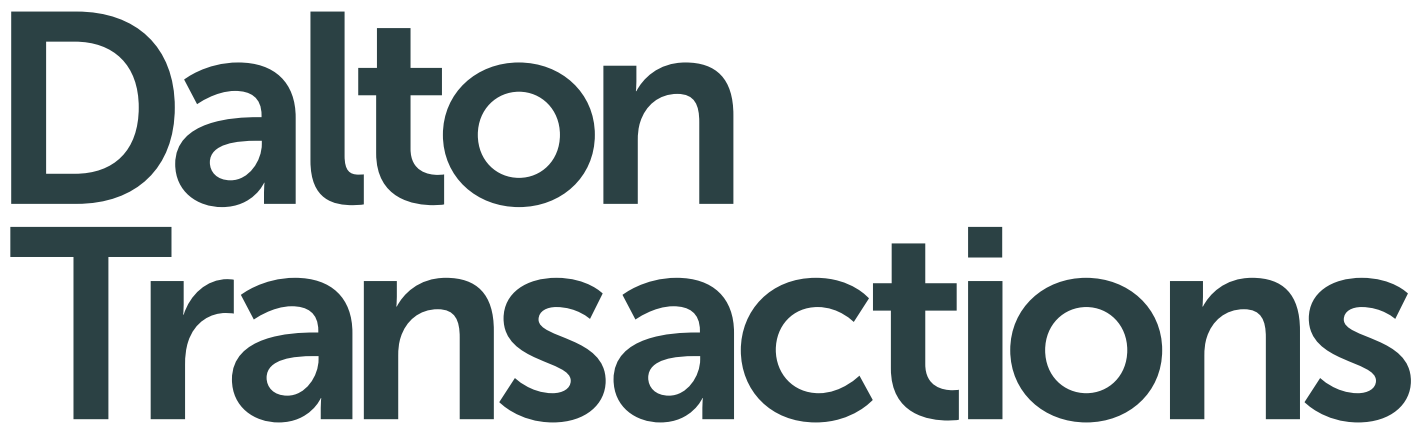

An international journal of inorganic chemistry rsc.li/dalton

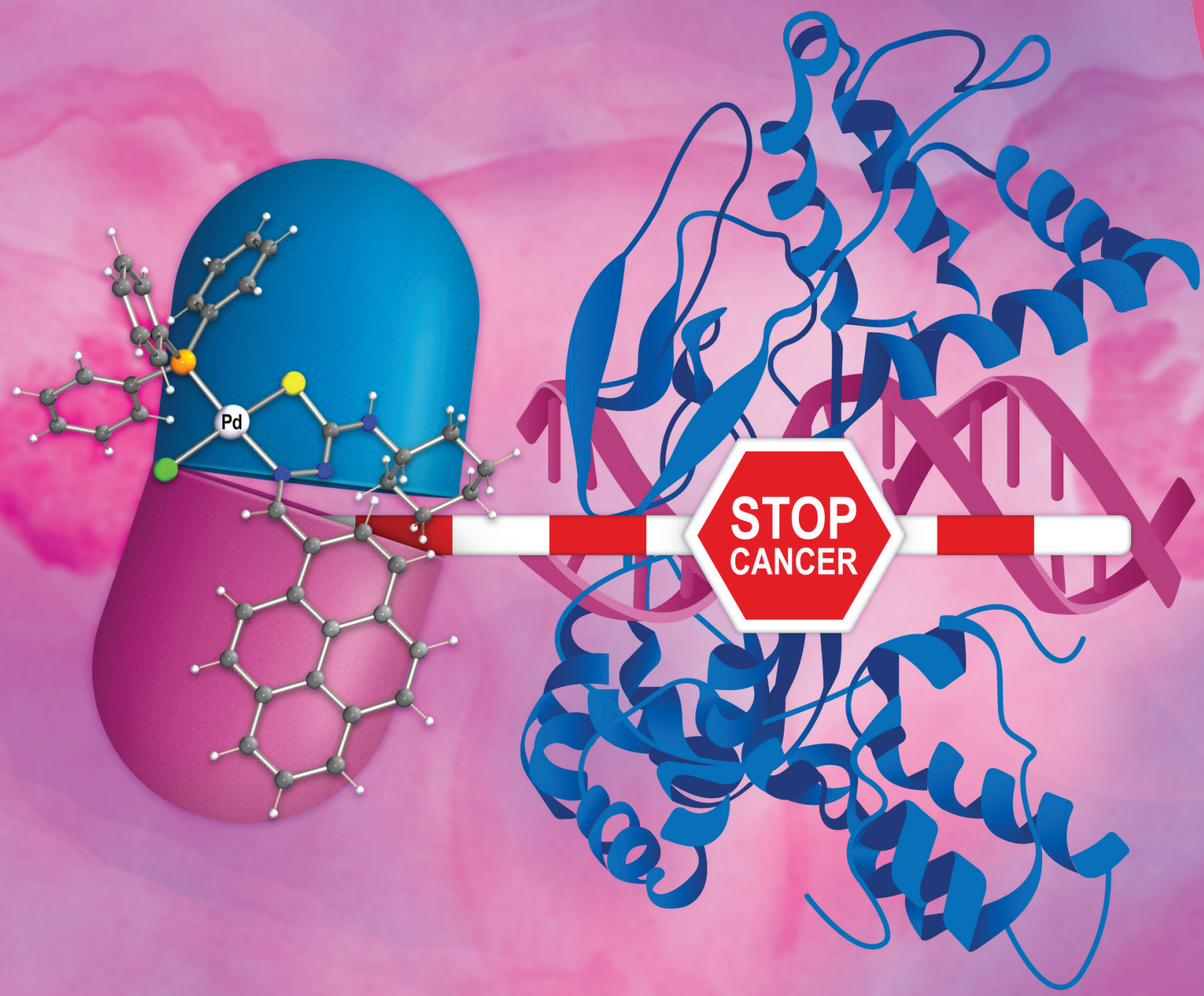




\section{(A) Check for updates}

Cite this: Dalton Trans., 2019, 48 , 16509

Received 18th June 2019,

Accepted 24th September 2019

DOI: $10.1039 / c 9 d t 02570 \mathrm{~g}$

rsc.li/dalton

\title{
Palladium(II) complexes with thiosemicarbazones derived from pyrene as topoisomerase IB inhibitors $\uparrow$
}

\author{
Carolina G. Oliveira, (D) ${ }^{\text {a,b,c }}$ Isolda Romero-Canelón, (D) ${ }^{c, d}$ Monize M. Silva, ${ }^{e}$ \\ James P. C. Coverdale, (D) e Pedro Ivo S. Maia, ${ }^{f}$ Alzir A. Batista, (D) e Silvia Castelli, ${ }^{9}$ \\ Alessandro Desideri, ${ }^{9}$ Peter J. Sadler (D) ${ }^{*}$ and Victor M. Deflon (D) $* a$
}

\begin{abstract}
New palladium complexes with thiosemicarbazonate ligands derived from pyrene exhibit potent antiproliferative activity against A2780 and cisplatin-resistant A2780Cis human ovarian cancer cells, which is dependent on substituent groups of the thiosemicarbazone ligands. Cellular accumulation and distribution studies confirmed that palladium enters the cell nucleus. DNA and topoisomerase IB studies show that one complex is a potent TopIB inhibitor, with selectivity for cancer versus normal cells.
\end{abstract}

\section{Introduction}

Thiosemicarbazones (TSCs) have been extensively studied due to their ability to chelate several metal ions ${ }^{1}$ and to suppress tumor growth by inhibiting ribonucleotide reductase (RR), a key enzyme required for DNA synthesis. ${ }^{2,3}$ Another well-known target for some TSCs derivatives is Topoisomerase (Top), responsible for DNA topology regulation during cell division. ${ }^{4}$ Recently, it was shown that the cytotoxicity of Dp44mT (di-2-pyridylketone-4,4-dimethyl-3-thiosemi-carbazone, Chart 1) against breast cancer cells is caused by poisoning topoisomerase IIa. ${ }^{5}$ Dp44mT is structurally similar to triapine (Chart 1), a compound which has undergone Phase 1 and 2 clinical trials. ${ }^{6,7}$ Both topoisomerase I (Top I) and topoisomerase II (Top II) have been established as effective molecular targets for many antitumor drugs. Several transition metal complexes have been shown to react with topoisomerase IB and act as poisons and/or catalytic inhibitors, since tumor cells present

\footnotetext{
${ }^{a}$ São Carlos Institute of Chemistry, University of São Paulo, 13560-970 São Carlos, Brazil.E-mail: deflon@iqsc.usp.br

${ }^{b}$ Institute of Chemistry, Federal University of Uberlândia, 38400-902 Uberlândia, Brazil

${ }^{c}$ Department of Chemistry, University of Warwick, CV4 7AL Coventry, UK

${ }^{d}$ School of Pharmacy, University of Birmingham, B15 2TT Birmingham, UK

${ }^{e}$ Department of Chemistry, Federal University of São Carlos, 13565-905 São Carlos, Brazil

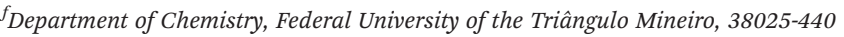
Uberaba, Brazil

${ }^{g}$ Department of Biology, University of Rome Tor Vergata, Via Della Ricerca Scientifica, 00133 Rome, Italy

$\dagger$ Electronic supplementary information (ESI) available. CCDC 1866632-1866635. For ESI and crystallographic data in CIF or other electronic format see DOI: $10.1039 / \mathrm{c} 9 \mathrm{dt} 02570 \mathrm{~g}$
}

high levels of Top enzymes. ${ }^{8,9}$ Top IB is the cellular target of camptothecin (CPT), a compound which generated the analogues topotecan and irinotecan, currently in clinical use to treat ovarian and colorectal cancers. ${ }^{10,11}$ Besides, the functionalization of TSCs provides a strategy to improve their efficiency and to incorporate specific properties. A pyrene group present in a thiosemicarbazone compound might bring new characteristics to the ligand, like fluorescence, ${ }^{12}$ that would enable its use as a luminescent probe for tracking complexes inside cells. Furthermore, the intercalating properties of pyrene can be used to inhibit cellular DNA replication. ${ }^{13,14}$ Hence, thiosemicarbazone ligands containing a pyrene moiety (Chart 1) might be promising to achieve metal complexes with mechanisms of action different from cisplatin, making them potentially active against platinum-resistant cell lines.

In addition to the potential use of thiosemicarbazones in cancer therapy, their derivatives with metal complexes are of considerable interest. New metal complexes might have increased efficacy and the possibility of overcoming resistance, which are the major limitations of the platinum anticancer drugs used in chemotherapy. ${ }^{15,16}$ In this regard, palladium

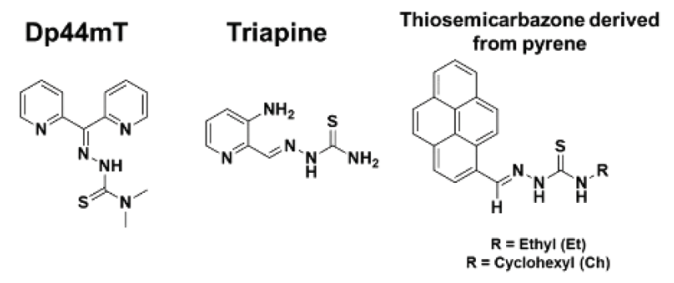

Chart 1 Molecular structure of thiosemicarbazones Dp44mT, triapine and the ligands studied here. 
complexes are natural analogues of platinum. However, palladium complexes usually exhibit high lability towards ligand exchange which limits their use. ${ }^{17}$ The use of thiosemicarbazone chelating ligands is a strategy to suppress this problem. Furthermore, the coordination of such ligands to palladium could give rise to compounds with a mechanism of action distinct from that of 'cisplatin like' complexes, since thiosemicarbazone derivatives complexes have shown different molecular targets. ${ }^{5,18,19}$

In this work, new palladium complexes derived from pyrene thiosemicarbazones were prepared, and designed to have sufficient stability against hydrolysis in solution together with a 'non-cisplatin like' mechanism of action against cancer cells, to overcome the acquired resistance of platinum-based drugs. In view of such potential, the compounds have been studied against A2780 and cisplatin-resistant A2780Cis cancer cell lines and also towards non cancer cells (MRC5). Furthermore, the complexes, cellular accumulation and distribution, interaction with DNA and potential activity as TopIB inhibitors were evaluated to explore their mechanism of action.

\section{Results and discussion}

\section{Synthesis and characterization of the compounds}

The ligands HPrR ( $\mathrm{R}$ = ethyl and cyclohexyl) were synthesized via condensation reactions of the corresponding thiosemicarbazide derivative with 1-pyrenecarboxaldehyde (more details in ESI $\dagger)$. The synthesis of the complexes $\left[\mathrm{PdCl}\left(\mathrm{PPh}_{3}\right)(\mathrm{PrCh})\right](\mathbf{1})$ and $\left[\mathrm{PdCl}\left(\mathrm{PPh}_{3}\right)(\mathrm{PrEt})\right](2)$ consisted on 1:1 reactions between $\left[\mathrm{PdCl}_{2}(\mathrm{MeCN})_{2}\right]$ and the appropriate HPrR ligand, with final addition of $\mathrm{PPh}_{3} \cdot{ }^{1} \mathrm{H}$ and ${ }^{13} \mathrm{C}$ NMR results support the proposed structures for all ligands and complexes prepared. The palladium complexes were further studied by ${ }^{31} \mathrm{P}$ NMR. The purity of these compounds was confirmed by elemental analyses and HPLC studies. The high resolution electrospray ionization mass spectrometry (ESI-MS) spectra showed peaks for $[\mathrm{M}+\mathrm{Na}]^{+}$for the free ligands and $[\mathrm{M}-\mathrm{Cl}]^{+}$for the palladium complexes $(\mathrm{m} / \mathrm{z} 752.1485$ for 1 and $\mathrm{m} / \mathrm{z} 698.1019$ for 2$)$, indicating that the $\mathrm{Pd}-\mathrm{Cl}$ bond breaks under the experimental conditions used.

The absorption and emission spectra of the free ligands and complexes were recorded. The ligands HPrCh and HPrEt absorb in the region 382-407 $\mathrm{nm}$ and around $282 \mathrm{~nm}$. These bands are most probably due to $\pi-\pi^{*}$ electronic transitions associated to the polycyclic aromatic fragment of the ligands. ${ }^{20}$ The electronic spectra of complexes $\mathbf{1}$ and $\mathbf{2}$ are similar, displaying strong absorptions in the $280-410 \mathrm{~nm}$ range. These bands may be attributed to a combination of intraligand and ligand-to-metal charge transfer (LMCT) transitions. ${ }^{21}$

The room temperature emission spectroscopic properties of the thiosemicarbazone ligands were investigated using an excitation wavelength of $415 \mathrm{~nm}$. The emission spectra obtained for both free ligands show two emission bands, at 429 and $448 \mathrm{~nm}$, while complexes $\mathbf{1}$ and $\mathbf{2}$ display only one broad band at $540 \mathrm{~nm}$. The fluorescence intensity for both complexes 1 and 2

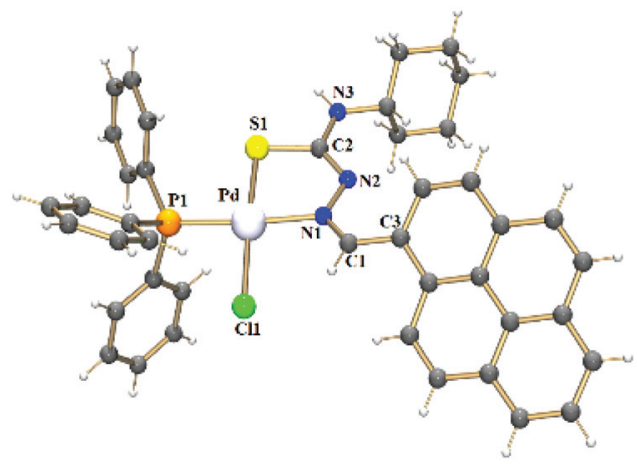

Fig. 1 Crystal structure of the complex 1.

is clearly less than that of the respective free ligands, evidence that the fluorescence is quenched in the metal complexes. ${ }^{22}$

$\mathrm{X}$-ray crystal structure analyses were determined for the ligands HPrCh and HPrEt (ESI, Fig. S1 $\dagger$ ) and complexes 1 and 2. Fig. 1 shows the molecular structure of complex $\mathbf{1}$, while that of complex 2 is in Fig. S2.† The molecular structures of both the complexes are very similar and show that the metal center is coordinated by the thiosemicarbazone ligands in monoanionic bidentate mode through the nitrogen and sulfur atoms, forming a 5-membered ring. The $\mathrm{PPh}_{3}$ phosphorus atom and the chlorido ligand occupy the remaining coordination sites, forming a distorted square-planar environment around the palladium(II) atom. The bond distances $\mathrm{Pd}-\mathrm{N}(1)$, $\mathrm{Pd}-\mathrm{S}(1), \mathrm{Pd}-\mathrm{Cl}(1)$ and $\mathrm{Pd}-\mathrm{P}(1)$ for both complexes 1 and 2 are comparable with those of other thiosemicarbazone derivatives reported in literature. ${ }^{23-25}$ Upon complexation with the metal ion, an elongation of the $\mathrm{S}(1)-\mathrm{C}(2)$ bond length is observed, in accordance with the coordination via the sulfur atom in a thioenolate form. The $\mathrm{N}(2)-\mathrm{C}(2)$ bond lengths in $\mathbf{1}$ [1.294(3) $\mathrm{A}]$ and in $2[1.302(3) \AA]$ are also consistent with the deprotonation of the thiosemicarbazone ligands after coordination, as observed for other thiosemicarbazone derivatives. ${ }^{26,27}$ Selected bond lengths and angles are listed in Tables S1 and S2. $\dagger$

The stability of complex 1 was monitored by ${ }^{1} \mathrm{H}$ and ${ }^{31} \mathrm{P}$ NMR in DMSO- $d_{6}: \mathrm{D}_{2} \mathrm{O}(80 \%: 20 \%)$ solution for a 24 -hour period. The spectra remained unchanged during the assay time, showing that the compound does not hydrolyze under such conditions (Fig. S3†).

\section{Antiproliferative activity of the compounds}

Biological studies were carried out on A2780 human ovarian carcinoma cells for both ligands and complexes. The complexes were further evaluated against A2780Cis (human ovarian carcinoma cisplatin-resistant cells). The results are shown in Table 1 . The free ligands were inactive towards the A2780 cell line, with $\mathrm{IC}_{50}$ values $>50 \mu \mathrm{M}$. In contrast, the complexes are highly potent. Changing the $\mathrm{R}$ substituent group in the thiosemicarbazone ligand affects the antiproliferative activity of the complex, as observed for complexes $\mathbf{1}$ (cyclohexyl derivative, $\left.\mathrm{IC}_{50}=7.59 \mu \mathrm{M}\right)$ and $2\left(\mathrm{R}=\right.$ ethyl, $\left.\mathrm{IC}_{50}=0.74 \mu \mathrm{M}\right)$. The experiments using cisplatin-resistant A2780Cis cell line 
Table $1 \quad I_{50}$ values for the compounds. RF: resistance factor. SF: selectivity factor. Nd: not determined. CARB: carboplatin

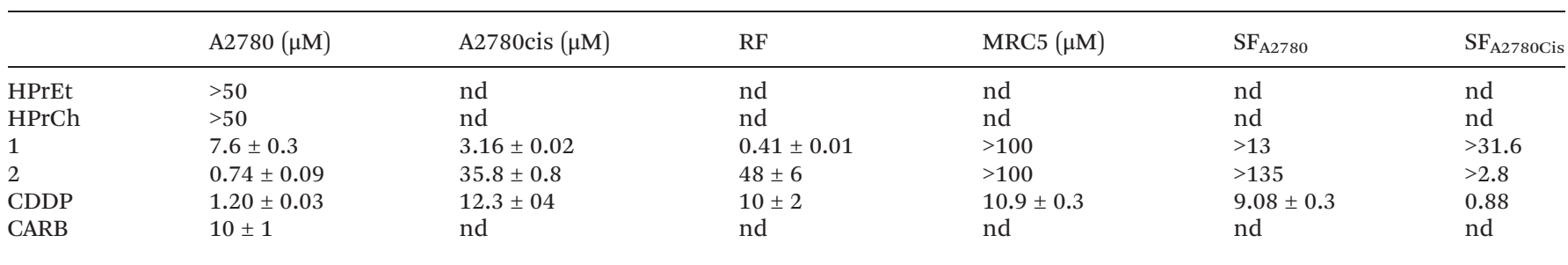

showed that the potency of complex 1 is increased when compared to that observed for $\mathrm{A} 2780$, with an $\mathrm{IC}_{50}$ value of $3.16 \pm$ $0.02 \mu \mathrm{M}$. In contrast, complex 2 loses its potency in A2780 cells resistant to cisplatin, with the $\mathrm{IC}_{50}$ value increasing to $35.8 \pm$ $0.8 \mu \mathrm{M}$. Cisplatin (CDDP) cross-resistance factors are shown in Fig. 2A (values in Table 1). The bars are expressed as the ratio between the $\mathrm{IC}_{50}$ values in the resistant cell line divided by the $\mathrm{IC}_{50}$ values for the parental cell line. These results suggest that complex 1 may have a different mechanism of action compared to CDDP, since this complex overcomes CDDP resistance and increases potency in the A2780Cis cells, with a cross-resistance factor of $0.41 \pm 0.01 \mu \mathrm{M}$. On the other hand, the resistance factor for complex $2(48 \pm 0.6)$ is very high compared to complex 1 and cisplatin, being less potent in A2780cis. Additionally, we investigated activity of the complexes towards non-cancerous cell line MRC-5 human embryonal lung fibroblasts (Table 1). The complexes exhibit high $\mathrm{IC}_{50}$ values for MRC5 human fibroblasts, showing low toxicity against healthy normal cells. Both palladium(II) complexes are nontoxic towards the healthy cells and present relatively high activity, affording high SF values for A2780 cells as well as for A2780Cis. In the case of A2780, complex 2 is the most selective $\left(\mathrm{SF}_{\mathrm{A} 2780}>135\right)$. On the other hand, considering the selectivity for the cisplatin resistant cell line, complex 1 presents the higher selectivity $\left(\mathrm{SF}_{\mathrm{A} 2780 \mathrm{Cis}}>31.6\right)$. In both cell lines, the complexes are more selective than cisplatin, with $\mathrm{SF}=9.08 \pm 0.3$, Table 1. Therefore, complex 1 appears to be a promising candidate to circumvent cisplatin resistance in ovarian cancer cells.
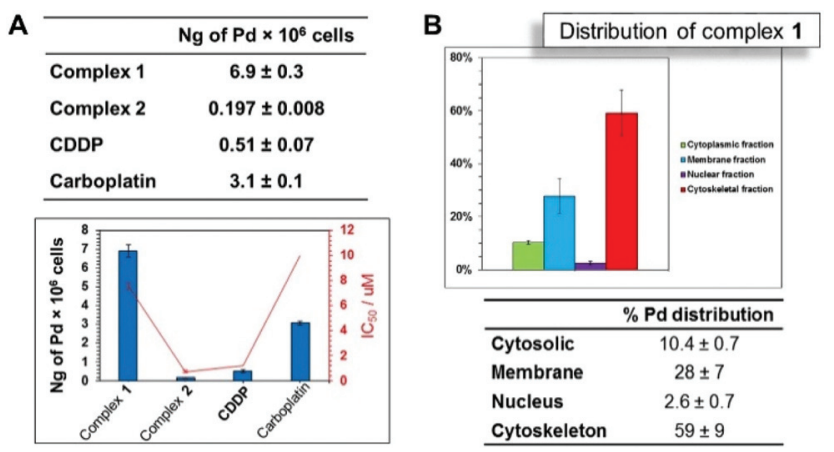

Fig. 2 (A) Cellular accumulation of palladium (ng Pd per $10^{6}$ cells) (up) uptake results and correlation of $\mathrm{IC}_{50}$ values $(\mu \mathrm{M})$ for complexes 1 and 2 (down). (B) Distribution of Pd for complex 1 in A2780 ovarian cells. Concentration used was $\mathrm{IC}_{50}$, pre-incubation time in drug free medium was $24 \mathrm{~h}$ and drug exposure time was $24 \mathrm{~h}$.

\section{Cellular accumulation and distribution in A2780 cell line}

The cellular accumulation of the palladium complexes, cisplatin and carboplatin was determined in A2780 cells, in order to correlate with the $\mathrm{IC}_{50}$ values in this cell line. The structural modification of changing a cyclohexyl group to an ethyl group affected significantly the cellular uptake. The results indicate that the accumulation for complex $\mathbf{1}(\mathrm{R}=$ cyclohexyl) is higher than that of complex 2 ( $\mathrm{R}$ = ethyl), with almost $7 \mathrm{ng}$ of Pd per $10^{6}$ cells (Fig. 2A) inside the A2780 cell line. These data are in accordance with the available amount of palladium for cellular uptake for complexes 1 and 2, which are $10 \mathrm{ng}$ and $1.1 \mathrm{ng}$ of palladium, respectively. Thus, $70 \%$ of complex 1 enters the cells, while only $18 \%$ of complex 2 is able to cross the cellular membrane. However, the results show that there is no correlation between cellular accumulation and the antiproliferative activities, since the complex $\mathbf{1}$ is the most lipophilic and presented the higher uptake but is less cytotoxic compared with complex 2.

We also investigated cell uptake by fluorescent imaging of A2780 cells treated with complex 1. It was possible to observe transport of the complex was into the interior of the cells, through a weak fluorescent green signal, when the compound was excited at $514 \mathrm{~nm}$. The cell distribution of complex 1 was determined. Fig. 2B shows the distribution of Pd and its percentage in four cellular fractions, the cytoplasm, membrane, nucleus and cytoskeletal fraction. It is notable that the highest amount is found in the cytoskeletal. The amount of palladium accumulated in the nuclear fraction is high ( $c a .3 \%)$, compared to the amount of platinum from cisplatin in the nuclear portion $<1 \% .^{28}$ Considering the amount of palladium in the nucleus, DNA binding studies were performed, since DNA is generally known to be the main target of cisplatin.

\section{DNA interaction}

DNA melting titration. DNA is a target of many drugs that are currently in clinical use or in advanced clinical trials. ${ }^{29}$ In order to understand the effect of the complexes on cancer cell lines some DNA interaction studies were carried out. Thermal denaturation of CT-DNA treated with the palladium complexes was studied. Due to the low solubility of the complexes in buffer solutions, the samples used in the measurements contained $5 \%$ of DMSO. The results obtained are summarized in Fig. 3A. The two complexes had no effect on the thermal stability of DNA, giving rise to only a minor change (increase) in melting temperature on incubation for 24 hours. 


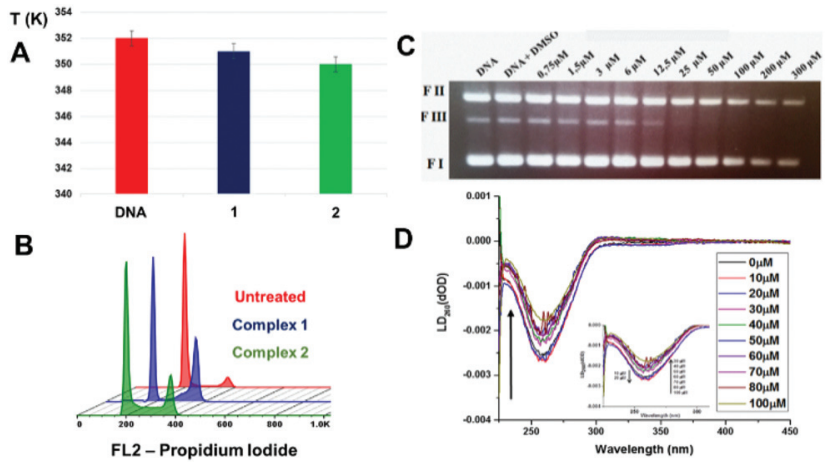

Fig. 3 (A) Comparison of the $T_{m}$ (K) for CT-DNA when incubated with palladium complexes 1 and 2 (B) FL2-H histograms obtained by flow cytometry for cell cycle analysis of control untreated cells; cells treated using $7.5 \mu \mathrm{M}$ of complex 1; cells treated using $0.7 \mu \mathrm{M}$ of complex 2; (C) ethidium bromide stained agarose gel $\left(0.5 \mathrm{~g} \mathrm{ml}^{-1}\right)$ of pBlue Script KSII(+) plasmid DNA $\left(0.25 \mu \mathrm{g} \mathrm{L}^{-1}\right)$ in the presence of increased concentration of the complexes after $30 \mathrm{~min}$ of incubation at $37^{\circ} \mathrm{C}$ : lane 1, plasmid DNA control; lane 2, plasmid DNA + DMSO control, lane 3-10, plasmid DNA + complexes 1 at $0.75,1.5,3,6,12.5,25,50,100,200$ and $300 \mu \mathrm{M}$. FI: supercoiled DNA, FII: opened circular, FIII: linear DNA; (D) linear dichroism (LD) spectra of $100 \mu \mathrm{M}$ DNA with increasing concentration of complex 1. For all experiments, drug exposure time was $24 \mathrm{~h}$, cells were treated with RNAse and stained using PI.

Linear dichroism. Linear dichroism (LD) of DNA in the presence of the metal complexes was studied. LD titration of ctDNA with complex 1 and the resulting titration curve is shown in Fig. 3D. No additional LD peaks were observed in the visible part of the spectrum. In the UV range, weak signals were observed at high compound concentrations, but these are obscured by the strong DNA signals in those regions. The results of the LD titrations have shown a minor increase in the LD signal only for the two first concentrations used, 10 and $20 \mu \mathrm{M}$, of complex added. From $30 \mu \mathrm{M}$ to $100 \mu \mathrm{M}$ a slight decrease in the LD signal was observed, indicative of kinking or aggregation upon binding the DNA strands. ${ }^{30}$ This phenomenon results in a lower linearity of DNA, causing a decrease or even complete loss of the negative signal at $260 \mathrm{~nm}$, indicative of a groove binder instead of an intercalator. ${ }^{31}$ However, the discreet changes observed in the LD spectra compared with the spectrum in absence of complex ( $0 \mu \mathrm{M}$, black line) are inconclusive.

DNA cleavage studies. In control experiments, where the complex was absent (lane 1) or only DNA-DMSO (lane 2) were incubated, no photocleavage was observed (Fig. 3C). The DNA cleavage studies performed for the palladium complexes in different concentrations show that at low concentrations the complexes do not have a strong interaction with plasmid DNA.

Flow cytometry. The cell cycle histograms are shown in Fig. 3B. Despite of the structural similarity of complexes $\mathbf{1}$ and 2, the experimental results have indicated different effects over the cell cycle profile of A2780 cells. In the control experiment, the $\mathrm{G} 2 / \mathrm{M}$ and $\mathrm{S}$ phases represent $7.9 \%$ and $18.6 \%$, respectively, of the cell population, but upon treatment with complexes 1 and 2 (cells treated using equipotent $\mathrm{IC}_{50}$ concentrations) the cell cycle was arrested at the $\mathrm{G} 2 / \mathrm{M}$ stage for complex 1 and in the $S$ phase for complex 2. The population in G2/M phase increases after $24 \mathrm{~h}$ of exposure to the complex 1 (from $7.9 \%$ to $30 \%$ ), together with a slight rise of the population in $S$ stage as well (from $18.6 \%$ to $24 \%$ ). In contrast, complex 2 causes arrest in the $S$ phase, with an increase from $18.6 \%$ to $38.2 \%$. These results show that complex 2 induced DNA damage and blocked DNA synthesis in the cells which consequently induces S-phase arrest. It is well established that the cytotoxicity of camptothecin is related to a collision mechanism between replication forks and Top I cleavable complex. ${ }^{32}$ This collision is consistent with the generally accepted notion that DNA damage leads to cell cycle arrest interfering with the $\mathrm{S}$ phase, causing cell cycle arrest at the G2 phase of the cell cycle. Consequently, when a damage repair is difficult or incomplete, the cells undergo apoptosis. ${ }^{33}$ A similar inhibition of the cell cycle at the G2/M phase has been recently observed for comparable ruthenium thiosemicarbazone complexes. ${ }^{34}$ The details of the cell cycle assay for the palladium complexes are shown in Table S4 (ESI $\dagger$ ).

Topoisomerase IB assays. The DNA interaction experiments did not clearly indicate if DNA might be a target for these complexes. So, TopIB inhibition studies were performed to investigate if this enzyme, that is deeply involved in DNA replication, repair and transcription, could be a possible target. The efficacy of the free ligands and complex 1 in the inhibition of TopIB was tested through supercoiled plasmid relaxation assays. Complex 1 inhibited the enzyme at a concentration of $0.75 \mu \mathrm{M}$ with complete inhibition at $12.5 \mu \mathrm{M}$ (Fig. 4). It is interesting to note that the free ligands did not inhibit the enzyme appreciably at comparable concentrations (see Fig. S4 $\dagger$ ), which is in accordance with the lack of cytotoxicity presented by those compounds (Table 1).

An analysis of the cleavage and religation kinetics was carried out in order to better understand the modality of topoisomerase I inhibition by complex 1. The cleavage assay was carried out using the CL14/CP25 suicide substrate, radiolabelled at the $5^{\prime}$ end of the CL14. The enzyme is able to cleave this substrate but it is not able to carry on the religation step

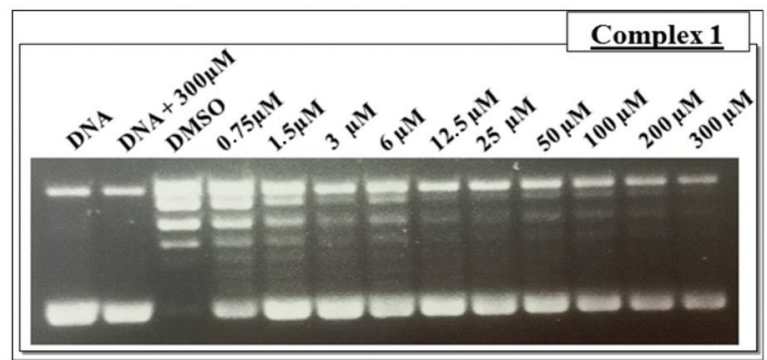

Fig. 4 Relaxation of negative supercoiled plasmid DNA by TopIB in presence of increasing concentrations of complex 1. Lane 1, no protein added; lane 2, control reaction with DNA and the maximum compound concentration $(300 \mu \mathrm{M})$; lane 3, positive control reaction with DNA and enzyme in absence of the compound. The reaction products were resolved in an agarose gel and visualized with ethidium bromide. SC, supercoiled plasmid DNA. 


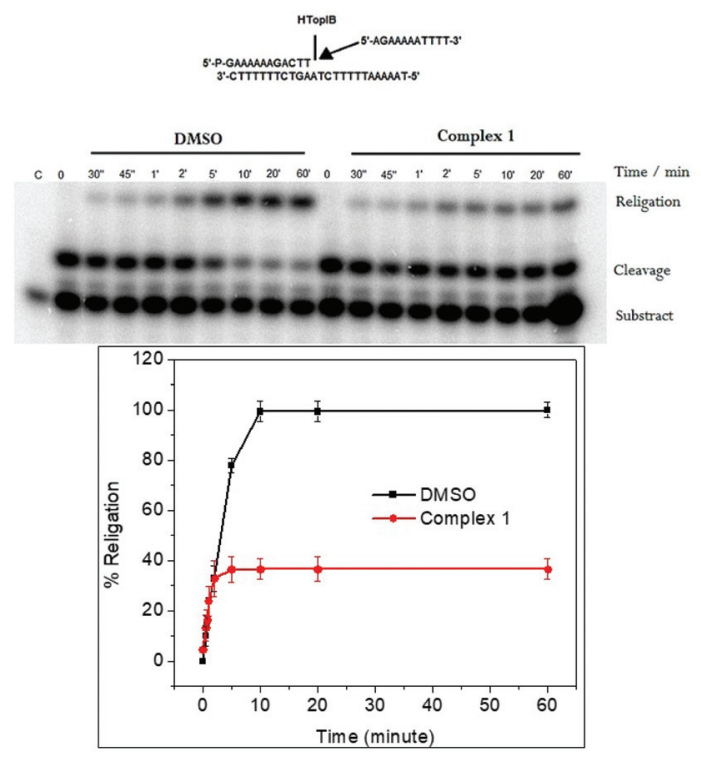

Fig. 5 Upper panel: Gel analysis of the religation kinetics with the CL14/CP25 substrate for TopIB in DMSO (lanes 2-9) and in presence of $25 \mu \mathrm{M}$ of complex 1 (lanes 10-18). Lower panel: The graphic shows the percentage of the religation product plotted at different times for topoisomerase IB. The data reported are the average \pm SD of three independent experiments.

because the cleaved dinucleotide is too short to be religated. ${ }^{35}$ The PAGE analysis of the reaction products, as a function of time, is shown in Fig. $\mathrm{S} 5 \dagger$ (upper panel), where the band corresponding to the cleaved DNA fragment is indicated as "cleavage". It is interesting that the substrate is cleaved in a fast and efficient way either in the absence or in the presence of complex 1 at $25 \mu \mathrm{M}$ concentration, i.e. a concentration that produce full relaxation inhibition (Fig. 4). The complete inability of complex 1 to inhibit the cleavage reaction is confirmed by plotting the percentage of the cleavage product as a function of time in presence and absence of the compound (Fig. S4,† lower panel).

The religation reaction was carried out by incubating, for 30 min, the oligonucleotide CL14/CP25 substrate with the TopIB enzyme, allowing the enzyme substrate complex to produce the cleaved complex (Fig. 5). After the cleavage has occurred, the R11 complementary strand is added, to start the religation process. At different times, aliquots were removed, treated with SDS, trypsinized and analyzed by PAGE electrophoresis (Fig. 5, upper pannel). The percentage of religation, plotted in Fig. 5 (lower panel), shows that in the presence of $25 \mu \mathrm{M}$ complex 1 the inhibitory effect is $>60 \%$. This result is very interesting since it clearly shows that complex $\mathbf{1}$ acts as a poison since it is able to inhibit the DNA religation but not the cleavage.

\section{Conclusions}

In conclusion, we have described the synthesis and characterization of stable new palladium(II) complexes with thiosemicar- bazonate ligands derivatized with pyrene. The in vitro biological data show promising low micromolar antiproliferative activity against A2780 and also A2780cis resistance cell lines. Complexes 1 and 2 were relatively less-toxic towards normal cells, but complex $\mathbf{2}$, in contrast to complex $\mathbf{1}$, was cross-resistant with the anticancer drug cisplatin I in ovarian cancer cell lines. Cell cycle studies in A2780 ovarian cells showed that complexes 1 and 2 exhibit cytotoxicity by causing G2/M and S phase arrest. Investigations of the mechanism of action, show that TopIB is a plausible target for complex $\mathbf{1}$. Interestingly the compound inhibits the religation reaction without inhibiting the DNA cleavage. TopIB can be inhibited by several compounds and the inhibitors are divided into two classes depending on the different ways they interact with the enzyme. ${ }^{36-38}$ Poisons inhibit the enzyme at the level of the religation stabilizing the DNA-TopI cleavage complex and catalytic inhibitors prevent the DNA binding or inhibit the cleavage reaction. ${ }^{39-41}$ Some of them are able to inhibit both the cleavage and religation reaction. ${ }^{10,42}$ The poisons, such as camptothecin (CPT), are the most interesting inhibitors, in fact CPT derivatives such as topotecan and irinotecan are in clinical use. $^{43,44}$ The here studied complex 1 behaves as a poison making it an interesting candidate to chemotherapy. Moreover, since resistance is one of the major challenges to be overcome in the use of chemotherapy for cancer treatment, palladium complexes which are active against resistant A2780cis cell lines are interesting as alternative antitumor agents. Therefore, the complexes studied here might be considered promising lead candidates for cancer therapy.

\section{Experimental section}

\section{General methods and materials}

Chemistry. 1-Pyrenecarboxaldehyde, 4-etyl-thiosemicarbazide, analytical reagents grade chemicals and solvents were purchased from Sigma-Aldrich and used without further purification. The 4-cyclohexyl-3-thiosemicarbazide and $\left[\mathrm{PdCl}_{2}(\mathrm{MeCN})_{2}\right]$ were prepared as described previously. ${ }^{45,46}$ Fourier transform infrared spectroscopy. FTIR spectra between 400 and $4000 \mathrm{~cm}^{-1}$ were measured via the Potassium Bromide $(\mathrm{KBr})$ pellet method using a Shimadzu IR Prestige-21 spectrophotometer. ${ }^{1} \mathrm{H},{ }^{31} \mathrm{P}$ and ${ }^{13} \mathrm{C}$ NMR spectra were acquired in $5 \mathrm{~mm}$ NMR tubes at $298 \mathrm{~K}$ on a Bruker DPX $400\left({ }^{1} \mathrm{H}=\right.$ 400.13 MHz, ${ }^{31} \mathrm{P}=161.98 \mathrm{MHz},{ }^{13} \mathrm{C}$ at $100.61 \mathrm{MHz}$ ) spectrometer. ${ }^{1} \mathrm{H}$ NMR chemical shifts were internally referenced to $\mathrm{CD}_{2} \mathrm{Cl}_{2}(5.32 \mathrm{ppm})$ for dichloromethane or DMSO $(2.50 \mathrm{ppm})$ for dimethyl sulfoxide- $d_{6}$. All data processing was carried out using ACDLabs software. Electrospray ionization mass spectra were obtained by preparing the samples in $10 \%$ acetone and $90 \% \mathrm{MeOH}(\mathrm{v} / \mathrm{v})$. The mass spectra were recorded with a scan range of $m / z \quad 400-1000$ for positive ions. CHN elemental analyses were carried out on a CE-440 elemental analyzer by Warwick Analytical (UK) Ltd or a PerkinElmer CHNS/O 2400 Series II equipment. LC-MS data were recorded on a Bruker Amazon X instrument coupled with an Agilent Technologies 
1200 series HPLC instrument was used. The HPLC column was an Agilent ZORBAX Eclipse Plus C18 $250 \times 4.6 \mathrm{~mm}$ column with a pore size of $5 \mu \mathrm{m}$. Mobile phases consisted of doubly deionized water $0.1 \%$ TFA and HPLC grade acetonitrile $0.1 \%$ TFA. Unfiltered volumes of $<200 \mu \mathrm{L}$ were injected and analyzed at a detection wavelength of $254 \mathrm{~nm}$. HPLC chromatograms were analyzed and integrated using DataAnalysis software. Sample injection volumes were $20 \mu \mathrm{L}$ and the mass spectrometer was operated in electrospray positive mode with a scan range of $50-2000 \mathrm{~m} / \mathrm{z}$. The following solvent gradient and $1 \mathrm{~mL} \mathrm{~min}^{-1}$ flow rate was used: time (min)/\% (B): 0 (min)/ 10\%, $30(\mathrm{~min}) / 80 \%, 40(\mathrm{~min}) / 80 \%, 41$ (min)/10\%, 55 (min)/ $10 \%$. For the biological assays as CT-DNA melting and linear dichroism (LD) titrations, CT-DNA was also obtained from Sigma Aldrich. The HPLC analysis of complexes was carried out on an Agilent Technologies 1200 series HPLC instrument with a VWD and $100 \mu \mathrm{L}$ loop, and an Agilent ZORBAX Eclipse Plus C18 $250 \times 4.6 \mathrm{~mm}$ column with a pore size of $5 \mu \mathrm{m}$ was used. The mobile phases used were (A) $\mathrm{H}_{2} \mathrm{O}$ and (B) MeCN both containing $0.1 \%$ of TFA (HPLC grade materials were used), following the solvent gradient flow described above. Samples were prepared at $100 \mu \mathrm{M}$ concentration in $100 \%$ of MeCN of complexes 1 and 2 using HPLC grade solvents and filtered through Iso-DiscTM filters (PTFE-4-4 $4 \mathrm{~mm} \times 0.45 \mu \mathrm{m}$ ). Sample volumes of $50 \mu \mathrm{L}$ were injected and analyzed at a detection wavelength of $254 \mathrm{~nm}$. The chromatograms were analysed using ChemStation software. UV-Vis spectra of solutions diluted in dichloromethane/DMSO were recorded using a Shimadzu UV-1800 spectrophotometer.

Orange crystals were produced via slow evaporation of the mother solution of complex 1 and mixture of solvents $\mathrm{CH}_{2} \mathrm{Cl}_{2}: \mathrm{MeOH}(1: 1)$ of complex 2 at room temperature. Data collection was performed at $296 \mathrm{~K}$ by applying Mo-K $\alpha$ radiation $(\lambda=71.073 \mathrm{pm})$ using a Bruker Kappa APEX II Duo diffractometer (Bruker®, Karlsruhe, Germany). The multi-scan method was applied for absorption correction. The structures were solved with SHELXS97 ${ }^{47}$ software using direct methods, and all non-hydrogen atoms were refined with anisotropic displacement parameters in SHELXL97. ${ }^{48}$ The hydrogen atoms were calculated at idealized positions using the riding model option of SHELXL2014. ${ }^{48}$ Table S3† presents more detailed information about the structure determinations. The structural data have been deposited in The Cambridge Crystallographic Data Centre with accession numbers of CCDC 1866632-1866635† for compounds HPrCh, HPrEt, 1 and 2, respectively.

Inductively Coupled Plasma-Optical Emission Spectrometry (ICP-OES) analyses were carried out on a PerkinElmer Optima 5300 DV series ICP-OES. The water (18.2 M 2 ) used for analysis was doubly deionized (DDW) using a Millipore Milli-Q water purification system and a USF Elga UHQ water deionizer. ICP standards for platinum $\left(1001 \pm 2 \mu \mathrm{g} \mathrm{ml} \mathrm{m}^{-1}\right.$, Fluka) and palladium $\left(1015 \mu \mathrm{g} \mathrm{mL} \mathrm{m}^{-1}\right.$, Aldrich) were diluted with $3.6 \% \mathrm{HNO}_{3}$ DDW to freshly prepare calibrants at concentrations of 50-700 $\mathrm{ppb}$, which were spiked with $\mathrm{NaCl}$ to match the salt content of the samples being analyzed. All Inductively Coupled Plasma-
Mass Spectrometry (ICP-MS) analyses were carried out on an Agilent Technologies 7500 series ICP-MS instrument. ICP standards were diluted with $3.6 \% \mathrm{HNO}_{3} \mathrm{DDW}$ to prepare freshly calibrants at concentrations of 0.1-1000 ppb. The ICP-MS instrument was set to detect Pd and Pt with typical detection limits of ca. 2 ppt using no-gas mode, with an internal calibration standard of $\operatorname{Er}(50 \mathrm{pp})$.

Preparation of the complexes. A solution of HPrR $(0.1 \mathrm{mmol})$ with $\left[\mathrm{PdCl}_{2}(\mathrm{MeCN})_{2}\right](0.1 \mathrm{mmol})$ in $\mathrm{MeCN}$ was stirred at ambient temperature for $24 \mathrm{~h}$. After this time, one mol equiv. $\mathrm{PPh}_{3}(26.2 \mathrm{mg}, 0.1 \mathrm{mmol}$ ) in MeCN was added. The reaction mixture was stirred at ambient temperature for $24 \mathrm{~h}$. Orange crystals formed for mother solution of $\mathbf{1}$ were collected by filtration after two days and crystals of 2 were obtained by recrystallization in mixture of DCM : $\mathrm{MeOH}(1: 1)$.

Data for $\left[\mathrm{PdCl}\left(\mathrm{PPh}_{3}\right)(\mathrm{PrCh})\right]$ (1) (788.6 $\left.\mathrm{g} \mathrm{mol}^{-1}\right)$. Color: orange. Yield: $40 \mathrm{mg}$ (76\%). M.P.: decomposes $278-280{ }^{\circ} \mathrm{C}$. IR $\left(\nu_{\max } / \mathrm{cm}^{-1}\right): 3394 \nu(\mathrm{N}-\mathrm{H}), 1583,1527 \nu(\mathrm{C}=\mathrm{N})+\nu(\mathrm{C}=\mathrm{C}), 1095$ $\nu(\mathrm{P}-\mathrm{C}), 746 \nu(\mathrm{C}=\mathrm{S}) .{ }^{1} \mathrm{H}$ NMR $\left(\mathrm{CD}_{2} \mathrm{Cl}_{2}\right): \delta 1.05-1.28(\mathrm{~m}, 6 \mathrm{H}, \underline{\mathrm{Ch}}-$ $\mathrm{H})$, 1.65-1.69 (m, 2H, Ch-H), 2.00-2.03 (m, 2H, Ch-H),

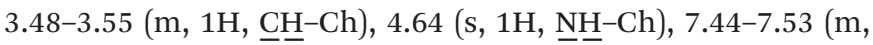
9H, $\left.\mathrm{PPh}_{3}-\mathrm{H}\right)$, 7.80-7.5 (m, 6H, $\left.\mathrm{PPh}_{3}-\mathrm{H}\right)$, 7.99-8.22 (m, 6H, Pr$\mathrm{H}), 8.62\left(\mathrm{~d}, 1 \mathrm{H},{ }^{3} \mathrm{~J}=8 \mathrm{~Hz}, \operatorname{Pr}-\mathrm{H}\right), 9.15\left(\mathrm{~d},{ }^{3} J=8 \mathrm{~Hz}, 1 \mathrm{H}, \operatorname{Pr}-\mathrm{H}\right)$, $9.77\left(\mathrm{~d},{ }^{3} \mathrm{~J}=4 \mathrm{~Hz}, 1 \mathrm{H}, \mathrm{Pr}-\mathrm{H}\right) .{ }^{31} \mathrm{P}$ NMR $\left(\mathrm{CDCl}_{3}\right): \delta 27.53 .{ }^{13} \mathrm{C}$ NMR (APT, $\left.\mathrm{CD}_{2} \mathrm{Cl}_{2}\right): \delta 24.92\left(\mathrm{CH}_{2}\right), 25.63\left(\mathrm{CH}_{2}\right), 32.89\left(\mathrm{CH}_{2}\right)$, $55.75(\mathrm{CH}), 123.16(\mathrm{CH}), 123.91(\mathrm{CH}), 124.42(\mathrm{C}), 124.51(\mathrm{C})$, $125.27(\mathrm{C}), 126.01(\mathrm{CH}), 126.05(\mathrm{CH}), 126.20(\mathrm{CH}), 127.26(\mathrm{CH})$, $128.20(\mathrm{CH}), 128.34(\mathrm{CH}), 128.77(\mathrm{CH}), 128.94(\mathrm{CH}), 129.14$ (CH), 129.91 (C), 130.56 (C), 130.63 (C), 131.11 (C), 131.13 (CH), 131.17 (CH), 131.24 (C), 132.73 (C), $134.54(\mathrm{CH}), 134.69$ $(\mathrm{CH}), 150.51(\mathrm{CH})$. Anal. Calcd for $\mathrm{C}_{42} \mathrm{H}_{38} \mathrm{ClN}_{3} \mathrm{PPdS} \cdot \mathrm{H}_{2} \mathrm{O}: \mathrm{C}$, 62.53; H, 4.87; N, 5.21\%. Found: C, 62.23; H, 4.69; N, 5.11\%. IV $\left(\nu_{\max } / \mathrm{cm}^{-1}\right): 3394 \nu(\mathrm{N}-\mathrm{H}), 1583,1517 \nu(\mathrm{C}=\mathrm{N})+\nu(\mathrm{C}=\mathrm{C})$, $1095 \nu(\mathrm{P}-\mathrm{C}), 746 \nu(\mathrm{C}-\mathrm{S})$. UV-Vis, $\mathrm{CH}_{2} \mathrm{Cl}_{2}$ solution concentration: $9.8 \times 10^{-5} \mathrm{M}\left[\lambda_{\max }\left(\varepsilon, \mathrm{L} \mathrm{mol}^{-1} \mathrm{~cm}^{-1}\right)\right]: 400.50 \mathrm{~nm}$ (41 430), $284.00 \mathrm{~nm}$ (32 448). $\mathrm{MS} \quad\left(\mathrm{ESI}^{+}\right): \mathrm{m} / \mathrm{z}$ for $\mathrm{C}_{42} \mathrm{H}_{38} \mathrm{ClN}_{3} \mathrm{PPdS}[\mathrm{M}-\mathrm{Cl}]^{+}$: calcd 752.1490, found 752.1485. HPLC: $R_{t}=40.5 \mathrm{~min}$ (at $\left.254 \mathrm{~nm}\right)$.

Data for $\left[\mathrm{PdCl}\left(\mathrm{PPh}_{3}\right)(\mathrm{PrEt})\right]$ (2) (734.59 $\left.\mathrm{g} \mathrm{mol}^{-1}\right)$. Color: orange. Yield: $38 \mathrm{mg}(52 \%)$. M.P.: $215-217{ }^{\circ} \mathrm{C}$. IR $\left(\nu_{\max } / \mathrm{cm}^{-1}\right)$ : $3356 \nu(\mathrm{N}-\mathrm{H}), 1584,1527 \nu(\mathrm{C}=\mathrm{N})+\nu(\mathrm{C}=\mathrm{C}), 1091 \nu(\mathrm{P}-\mathrm{C}), 756$ $\nu(\mathrm{C}=\mathrm{S}) .{ }^{1} \mathrm{H} \mathrm{RMN}\left(\mathrm{CD}_{2} \mathrm{Cl}_{2}\right): \delta 1.13\left(\mathrm{t},{ }^{3} \mathrm{~J}=6.0 \mathrm{~Hz}, 3 \mathrm{H},-\mathrm{CH}_{2} \underline{\mathrm{C}}_{3}\right)$, $3.31\left(\mathrm{dq},{ }^{3} J_{1}=6.0 \mathrm{~Hz},{ }^{3} J_{2}=3 \mathrm{~Hz}, 2 \mathrm{H},-\mathrm{NH}^{-} \underline{H}_{2} \mathrm{CH}_{3}\right), 4.82(\mathrm{~s}, 1 \mathrm{H}$, Nㅂ -Et), 7.47-7.57 (m, 9H, $\left.\mathrm{PPh}_{3}-\mathrm{H}\right), 7.78-7.84\left(\mathrm{~m}, 6 \mathrm{H}, \mathrm{PPh}_{3}-\right.$ H), 8.03-8.27 (m, 8H, Pr-H), 8.56 (d, $\left.{ }^{3} J=9 \mathrm{~Hz}, 1 \mathrm{H}, \mathrm{Pr}-\mathrm{H}\right), 9.18$ (d, $\left.{ }^{3} J=9 \mathrm{~Hz}, 1 \mathrm{H}, \operatorname{Pr}-\mathrm{H}\right), 9.72$ (d, $\left.1 \mathrm{H},{ }^{3} J=6 \mathrm{~Hz}, 1 \mathrm{H}, \mathrm{Pr}-\mathrm{H}\right) \cdot{ }^{31} \mathrm{P}$ NMR $\left(\mathrm{CD}_{2} \mathrm{Cl}_{2}\right): \delta 27.56 .{ }^{13} \mathrm{C} \mathrm{NMR}\left(\mathrm{APT}, \mathrm{CD}_{2} \mathrm{Cl}_{2}\right): \delta 14.45\left(\mathrm{CH}_{3}\right)$, $41.41\left(\mathrm{CH}_{2}\right), 123.17(\mathrm{CH}), 124.02(\mathrm{CH}), 124.41(\mathrm{C}), 125.34(\mathrm{C})$, $126.02(\mathrm{CH}), 126.05(\mathrm{CH}), 126.20(\mathrm{CH}), 127.26(\mathrm{CH}), 128.20$ $(\mathrm{CH}), 128.35(\mathrm{CH}), 128.75(\mathrm{CH}), 128.95(\mathrm{CH}), 129.11(\mathrm{CH})$, 129.88 (C), 130.56 (C), 130.61 (C), 131.11 (C), $131.15(\mathrm{CH})$, $131.18(\mathrm{CH}), 132.72(\mathrm{C}), 134.54(\mathrm{CH}), 134.68(\mathrm{CH}), 150.94(\mathrm{CH})$. Anal. Calcd for $\mathrm{C}_{38} \mathrm{H}_{31} \mathrm{ClN}_{3}$ PPdS: C, 62.13; H, 4.25; N, 5.72\%. Found: C, 61.51; H, 4.18; N, 5.64\%. UV-Vis, $\mathrm{CH}_{2} \mathrm{Cl}_{2}$ solution concentration: $5.1 \times 10^{-5} \mathrm{M}\left[\lambda_{\max }\left(\varepsilon, \mathrm{L} \mathrm{mol}^{-1} \mathrm{~cm}^{-1}\right)\right]$ : $408.00 \mathrm{~nm}$ (15 128), $393.50 \mathrm{~nm}$ (15 326), 286.50 (13 702). MS 
$\left(\mathrm{ESI}^{+}\right.$): $\mathrm{m} / z$ for $\mathrm{C}_{38} \mathrm{H}_{31} \mathrm{ClN}_{3} \mathrm{PPdS}[\mathrm{M}-\mathrm{Cl}]^{+}$: calcd 698.1019, found 698.1019. HPLC: $R_{t}=38.4 \mathrm{~min}$ (at $254 \mathrm{~nm}$ ).

Cell culture. A2780 and A2780Cis human ovarian carcinoma cells were obtained from the European Collection of Cell Cultures (ECACC) and used between passages 5 and 18 . MRC-5 human fetal lung fibroblasts were also obtained from the same source. All cell lines were grown in Roswell Park Memorial Institute medium (RPMI-1640) supplemented with $10 \% \mathrm{v} / \mathrm{v}$ of fetal calf serum, $1 \% \mathrm{v} / \mathrm{v}$ of $2 \mathrm{mM}$ glutamine and $1 \%$ $\mathrm{v} / \mathrm{v}$ penicillin/streptomycin. They were grown as adherent monolayers at $310 \mathrm{~K}$ in a $5 \% \mathrm{CO}_{2}$ humidified atmosphere and passaged at approximately $70-80 \%$ confluence.

In vitro growth inhibition assay. Briefly, 5000 cells were seeded per well in 96-well plates. The cells were pre-incubated in drug-free media at $310 \mathrm{~K}$ for $48 \mathrm{~h}$ before adding different concentrations of test compounds. Stock solutions of the $\mathrm{Pd}^{\mathrm{II}}$ complexes were firstly prepared in 5\% DMSO (v/v) and a mixture 0.9\% saline and RPMI-1640 medium (1:1) (v/v) following serial dilutions in RPMI-1640. The drug exposure period was $24 \mathrm{~h}$. After this, supernatants were removed by suction and each well was washed with PBS. The cells were allowed to recover for a further $72 \mathrm{~h}$ in drug-free medium at $310 \mathrm{~K}$. The SRB assay was used to determine cell viability. ${ }^{49}$ Absorbance measurements of the solubilized dye (on a BioRad iMark microplate reader using a $470 \mathrm{~nm}$ filter) allowed the determination of viable treated cells compared to untreated controls. IC $_{50}$ values were determined as duplicates of triplicates in two independent sets of experiments and their standard deviations were calculated.

\section{Metal accumulation in cancer cells}

Cell seeding. Briefly, $4 \times 10^{6}$ cells were seeded in a P100 Petri dish using $10 \mathrm{ml}$ of culture medium and incubated at $310 \mathrm{~K}$ for $24 \mathrm{~h}$.

Sample preparation. $100 \mu \mathrm{M}$ solution of each compound to be tested were prepared in cell culture medium containing $5 \%$ v/v DMSO. Exact concentration of palladium was determined by ICP-OES (using freshly prepared calibration standards, 50-700 ppb, with standard addition of sodium chloride to match the sample matrix). The stock solutions were diluted with culture medium to achieve final working concentration equal to $\mathrm{IC}_{50}$.

Drug addition. The supernatant medium was removed, and $10 \mathrm{~mL}$ of each compound to be tested was added to triplicate the Petri dishes. Cells were exposed to the drugs for $24 \mathrm{~h}$.

Drug removal. Supernatants were removed by suction. Cells were washed with PBS and detached using trypsin/EDTA and a single cell suspension was obtained using culture medium. Cells were counted using a hemocytometer, and centrifuged (1000 rpm, $5 \mathrm{~min}, 277 \mathrm{~K}$ ) to obtain whole-cell pellets.

Sample digestion. Cell pellets were digested in $72 \% \mathrm{v} / \mathrm{v}$ nitric acid using a CEM Discovery SP microwave reactor ( $3 \mathrm{~min}, 393 \mathrm{~K}, 150 \mathrm{~W}, 250 \mathrm{psi}$ ) then diluted to working acid concentration of $3.6 \% \mathrm{v} / \mathrm{v}$. Samples were analyzed using an Agilent 7500 series ICP-MS in both no-gas and He-gas mode. Calibration samples for Pd (0.1-1000 ppb) were freshly prepared in $3.6 \% \mathrm{v} / \mathrm{v}$ nitric acid. Total dissolved solids for ICP-MS analysis did not exceed $0.1 \%$ w/v. Final metal accumulation was reported as ng $\mathrm{Pd} \times 10^{6}$ cells and standard deviations were calculated.

Cellular metal distribution. Experiments were conducted similarly to the metal accumulation protocol described above, following identical cell seeding, sample preparation, and drug addition. Modifications during drug removal included the use of the fractionPREP kit from Biovision, according to manufacturer's instructions once the whole-cell pellets had been obtained. Sample digestion and ICP-MS metal quantification were conducted as above.

CT-DNA melting. The stability of DNA in the presence of the metal complexes was recorded by measuring the absorbance at $260 \mathrm{~nm}$ while increasing the temperature between 323 and $368 \mathrm{~K}$. The DNA concentration was determined by UV absorbance at $260 \mathrm{~nm}$ based on DNA base pairs $\pi-\pi^{*}$ transitions ${ }^{48}$ and the known extinction coefficient at this wavelength $(6600$ $\left.\mathrm{L} \mathrm{mol}{ }^{-1} \mathrm{~cm}^{-1}\right) .{ }^{50}$ The melting curves of untreated and treated CT-DNA were recorded using a fixed ratio of $1: 1 \mathrm{Pd}$ (II) : CT-DNA ( $45 \mu \mathrm{M}$ of both complex and CT-DNA). The value of the melting temperature $\left(T_{\mathrm{m}}\right)$ as the temperature when $50 \%$ of the present double-stranded CT-DNA converts into singlestranded CT-DNA was determined as the corresponding maximum on the first-derivative profile of the melting curves. Complexes were incubated for 24 hours with 5\% DMSO.

Linear dichroism (LD) titrations. All solutions were prepared in $1 \mathrm{mM}$ Tris ( $\mathrm{pH}$ 7.6), 5\% DMSO buffer. The CT-DNA concentration was kept constant throughout the experiment at $100 \mu \mathrm{M}$, and the complex 1 concentration was increased from 0 to $100 \mu \mathrm{M}$. DMSO concentration was kept constant at $5 \%$. Complex 1 were incubated for 24 hours with DNA before the LD measurement. The LD scans were run from $200 \mathrm{~nm}$ to $450 \mathrm{~nm}$ with 3 accumulations.

stabi analysis by flow cytometry. All flow cytometry experiments were carried out using a Becton Dickinson FACScan Flow Cytometer in the School of Life Sciences at Warwick University. Typically, A2780 cells were seeded in Petri dishes using $4 \times 106$ cells per plate. Experiments included $24 \mathrm{~h}$ of pre-incubation in drug-free media at $310 \mathrm{~K}$ in $\mathrm{CO}_{2}$ humidified atmosphere, followed by $24 \mathrm{~h}$ of drug exposure under the same conditions. After this, samples were collected after trypsinization, washed with PBS and stained in the dark with a mixture of propidium iodide and RNAse. After 30 min staining, cell samples were washed and set up for flow cytometry reading on the red channel FL-2.

DNA cleavage studies using agarose gel electrophoresis. In the gel electrophoresis experiments, supercoiled pBlue-Script $\mathrm{KSII}(+)$ DNA was incubated with increasing metal complexes concentrations for $30 \mathrm{~min}$ at $37^{\circ} \mathrm{C}$. $7.5 \mu \mathrm{L}$ of SDS $4 \times$ STOP dye were added (25\% Ficol 400, 2.5\% SDS, 25 mM EDTA, 0.03\% blue of bromofenol, $0.03 \%$ xilenocianol)and the samples were analyzed by $1 \%$ agarose gel electrophoresis, run for $18 \mathrm{~h}$ at $30 \mathrm{~V}$ in TBE buffer (Tris $50 \mathrm{mM}$, boric acid $45 \mathrm{mM}$ and $1 \mathrm{mM}$ of EDTA). The gel was stained with $0.5 \mu \mathrm{g} \mathrm{mL} \mathrm{m}^{-1}$ ethidium bromide, washed with distilled water, visualized by UV light, and photographed for analysis. 
Purification of human topoisomerase IB. Multicopy plasmids, YCpGAL1-e-hTopIBwt and YCpGAL1-e-hTopIBY723F were used for transformation of Saccharomyces cerevisiae TopI null strain EKY3 (ura3-52, his3_200, leu2 $\Delta$ 1, trp1 $\Delta 63$, top1: TRP1, MAT $\alpha$ ), as previously described. ${ }^{32}$ The plasmids have a galactose-inducible promoter and the constructs contain at the $\mathrm{N}$-terminal the sequence FLAG (DYKDDDY), indicated with "e". This sequence is recognized by the M2 monoclonal antibody and its purification was carried out using the ANTI-FLAG M2 Affinity Gel (Sigma-Aldrich) column. The transformed cells grew overnight on synthetic complement (SC)-uracil plus $2 \%$ dextrose. After dilution 1:100 in SC-uracil plus 2\% raffinose, cells were induced with $2 \%$ galactose for $6 \mathrm{~h}$. After enzyme extraction, the extracts were loaded into ANTI-FLAG M2 Affinity Gel (Sigma-Aldrich) column, already equilibrated according to manufactures' instructions. The FLAG-fusion topoisomerase IB was eluted by competition with five column volumes of a solution containing $200 \mu \mathrm{g} \mathrm{ml}^{-1}$ FLAG peptide in $50 \mathrm{mM}$ Tris- $\mathrm{HCl}, 150 \mathrm{mM} \mathrm{KCl} \mathrm{pH} \mathrm{7.4.} \mathrm{Glycerol} \mathrm{was} \mathrm{added} \mathrm{into}$ each collected fraction up to a final concentration of $40 \%$. All the fractions were stored at $-20{ }^{\circ} \mathrm{C}$.

DNA relaxation assays. The enzyme activity was assayed at $37{ }^{\circ} \mathrm{C}$, in $30 \mu \mathrm{l}$ of reaction volume containing $0.5 \mu \mathrm{g}$ of negatively supercoiled pBlue-ScriptKSII $(+)$ as a substrate in reaction buffer (20 mM Tris-HCl, $0.1 \mathrm{mM}$ EDTA, $10 \mathrm{mM} \mathrm{MgCl}_{2}, 50 \mu \mathrm{g}$ $\mathrm{ml}^{-1}$ acetylated BSA and $150 \mathrm{mM} \mathrm{KCl,} \mathrm{pH} \mathrm{7.5).} \mathrm{Reactions} \mathrm{were}$ stopped with $0.5 \%$ SDS after each time point. The effect of the compound on enzyme activity was measured by adding the indicated concentration of the compound to the reaction tube. DMSO was used as positive control, in a final concentration of $3.3 \%$. The samples were electrophoresed in $1 \%$ agarose gel in TBE buffer (50 mM Tris, $45 \mathrm{mM}$ boric acid, $1 \mathrm{mM}$ EDTA). The gels were stained with ethidium bromide $\left(0.5 \mu \mathrm{g} \mathrm{ml} \mathrm{ml}^{-1}\right)$, destained with water and photographed under UV illumination.

Kinetics of cleavage. The oligonucleotide substrate CL14 (5'GAAAAAAGACTTAG-3') was radiolabeled with $\left[\gamma^{-32} \mathrm{P}\right]$ ATP at its $5^{\prime}$ end. The CP25 complementary strand (5'-TAAAAATTTTTCTAAGTCTTTTTTC-3') was phosphorylated at its $5^{\prime}$ end with unlabeled ATP. The two strands were annealed at a twofold molar excess of CP25 over CL14, to permit a full formation of a partial duplex, that contains the enzyme preferred cleavage site, as already described. ${ }^{51}$ The cleavage reactions were carried out incubating TopIB enzyme with $20 \mathrm{nM}$ of partial duplex substrate in the presence of $25 \mu \mathrm{M}$ complex 1 at $37^{\circ} \mathrm{C}$. At different time points, $5 \mu \mathrm{L}$ of reaction solution were removed and the reactions were stopped with $0.5 \%$ SDS. DMSO was used as positive control. After ethanol precipitation, samples were resuspended in $6 \mu \mathrm{L}$ of $1 \mathrm{mg} \mathrm{mL}{ }^{-1}$ of trypsin and incubated at $37^{\circ} \mathrm{C}$, for $1 \mathrm{~h}$. Samples were analyzed using denaturing $7 \mathrm{M}$ urea/20\% polyacrylamide gel electrophoresis in TBE buffer. The percentage of cleaved substrate was determined by PhosphorImager and ImageQuant software comparing the intensity of the CL1 product, normalized to the total amount of radioactivity in each lane, with the maximal value obtained at the longest time for the enzyme in the absence of the compounds. The experiments were performed at least three times and a representative gel is shown.

Kinetics of religation. For kinetics of religation, we used the oligonucleotide CL14/CP25 (20 nM), prepared as explained previously. The substrate was incubated with TopIB enzyme for $30 \mathrm{~min}$ at $37^{\circ} \mathrm{C}$, in reaction buffer, allowing the enzyme to perform the cleavage. After the formation of the cleavage complex, $5 \mu \mathrm{L}$ sample of the reaction mixture were removed and used as the zero-time point. Religation reactions were initiated by adding a 200-foldmolar excess of R11 oligonucleotide (5'-AGAAAAATTTT-3') over the duplex CL14/CP25, in the presence or in the absence of compound. This allows the enzyme to perform the religation step, restoring a full duplex oligonucleotide, as the final product. DMSO was used as positive control. At time-course points, $5 \mu \mathrm{l}$ aliquots were removed and the reaction stopped with $0.5 \%$ SDS. After ethanol precipitation samples were resuspended in $6 \mu \mathrm{L}$ of $1 \mathrm{mg} \mathrm{mL}^{-1}$ trypsin and incubated at $37{ }^{\circ} \mathrm{C}$ for $1 \mathrm{~h}$. Samples were analyzed by denaturing $7 \mathrm{M}$ urea/20\% polyacrylamide gel electrophoresis in TBE buffer. The result was visualized by Phosphor Imager and quantified by ImageQuant software. The experiment was performed three times and a representative gel is shown.

\section{Conflicts of interest}

There are no conflicts to declare.

\section{Acknowledgements}

We thank the EPSRC (grant no. EP/F034210/1 to PJS) and Wellcome Trust (grant no $107691 / \mathrm{Z} / 15 / \mathrm{Z}$ to PJS and IRC) for support. The authors thank CNPq (Grant 141845/2013-9 and 201134/2015-2), CAPES (finance code 001), FAPESP (Grant 2009/54011-8) and the Minas Chemical Network (RQ-MG) supported by FAPEMIG (Project: CEX-RED-00010-14).

\section{References}

1 C. G. Oliveira, P. I. da S. Maia, P. C. Souza, F. R. Pavan, C. Q. F. Leite, R. B. Viana, A. A. Batista, O. R. Nascimento and V. M. Deflon, J. Inorg. Biochem., 2014, 132, 21.

2 E. O. Lopes, C. G. Oliveira, P. B. Silva, C. E. Eismann, A. C. Suárez, A. A. Menegário, C. Q. F. Leite, V. M. Deflon and F. R. Pavan, Int. J. Mol. Sci., 2016, 17, 1.

3 Z. G. Jiang, M. S. Lebowitz and H. A. Ghanbari, CNS Drug Rev., 2006, 12, 77.

4 T. K. Li and L. F. Liu, Annu. Rev. Pharmacol. Toxicol., 2001, 41, 53.

5 J. C. Yalowich, X. Wuc, R. Zhang, R. Kanagasabai, M. Hornbaker and B. B. Hasinoff, Biochem. Pharmacol., 2012, 84, 52.

6 C. A. Kunos and T. M. Sherertz, Front. Oncol., 2014, 4, 1.

7 C. A. Kunos, Oncol. Hematol. Rev., 2012, 8, 55. 
8 F. Bacher, E. A. Enyedy, N. V. Nagy, A. Rockenbauer, G. M. Bogná, R. Trondl, M. S. Novak, E. Klapproth, T. Kiss and V. B. Arion, Inorg. Chem., 2013, 52, 8895.

9 J. L. Nitiss, Nat. Rev., 2009, 9, 327.

10 S. Castelli, P. Katkar, O. Vassallo, M. Falconi, S. Linder and A. Desideri, Anticancer Agents Med. Chem., 2013, 13, 356.

11 J. Dancey and E. A. Eisenhauer, Br. J. Cancer, 1996, 74, 327.

12 S. Lim, K. A. Price, S. F. Chong, B. M. Paterson, A. Caragounis, K. J. Barnham, P. J. Crouch, J. M. Peach, J. R. Dilworth, A. R. White and P. S. Donnelly, J. Biol. Inorg. Chem., 2010, 15, 225.

13 A. Coleman and M. T. Pryce, Inorg. Chem., 2008, 47, 10980.

14 R. R. Avirah and G. B. Schuster, J. Photochem. Photobiol., 2013, 89, 332.

15 G. McGowan, S. Parsons and P. J. Sadler, Inorg. Chem., 2005, 44, 7459.

16 A. A. Ammar, R. Raveendran, D. Gibson, T. Nassar and S. A. Benita, J. Med. Chem., 2016, 59, 9035.

17 J. S. Casas, E. E. Castellano, J. Ellena, M. S. García-Tasende, M. L. Pérez-Parallé, A. Sánchez, Á. Sánchez-González, J. Sordo and A. Touceda, J. Inorg. Biochem., 2008, 102, 33.

18 A. Sîrbu, O. Palamarciuc, M. V. Babak, J. M. Lim, K. Ohui, E. A. Enyedy, S. Shova, D. Darvasiová, P. Rapta, W. H. Ang and V. B. Arion, Dalton Trans., 2017, 46, 3833.

19 B. M. Zeglis, V. Divilov and J. S. Lewis, J. Med. Chem., 2011, 54(7), 2391.

20 R. N. Prabhu and S. Pal, J. Chem. Sci., 2015, 127, 589.

21 P. I. S. Maia, A. Graminha, F. R. Pavan, C. Q. F. Leite, A. A. Batista, D. F. Back, E. S. Lang, J. Ellena, S. de S. Lemos, H. S. S. Araujo and V. M. Deflon, J. Braz. Chem. Soc., 2010, 21, 1177.

22 J. E. Expósito, M. Álvarez-Paíno, G. Aullón, J. A. Miguel and P. Espinet, Dalton Trans., 2015, 44, 16164.

23 P. Paul, P. Sengupta and S. Bhattacharya, J. Organomet. Chem., 2013, 724, 281.

24 J. Ruiz, M. D. Villa, N. Cutillas, G. López, C. Haro, D. Bautista, V. Moreno and L. Valencia, Inorg. Chem., 2008, 47, 4490.

25 J. S. Casas, E. E. Castellano, J. Ellena, M. S. García-Tasende, M. L. Pérez-Parallé, A. Sánchez, A. Sánchez-González, J. Sordo and A. Touceda, J. Inorg. Biochem., 2008, 102, 33.

26 S. Mandal, V. Kundi, D. K. Seth, K. Srikanth and P. Gupta, Polyhedron, 2014, 80, 290.

27 C. G. Oliveira, P. I. S. Maia, M. Miyata, F. R. Pavan, C. Q. F. Leite, E. T. Almeida and V. M. Deflon, J. Braz. Chem. Soc., 2014, 25, 1848.

28 B. T. Benedetti, E. J. Peterson, P. Kabolizadeh, A. Martínez, R. Kipping and N. P. Farrell, Mol. Pharmaceutics, 2011, 8, 940.
29 L. H. Hurley and F. L. Boyd, Trends Pharmacol. Sci., 1988, 9, 402.

30 A. Rodger, Sci. Prog., 2008, 91, 377.

31 S. Betanzos-Lara, N. P. Chmel, M. T. Zimmerman, L. R. Barrón-Sosa, C. Garino, L. Salassa, A. Rodger, J. L. Brumaghim, I. Gracia-Moraa and N. Barba-Behrens, Dalton Trans., 2015, 44, 3673.

32 M. A. Bjornsti, P. Benedetti, G. A. Vigilanti and J. C. Wang, Cancer Res., 1989, 49, 6318.

33 B. Zhivotovsky and G. Kroemer, Nat. Rev. Mol. Cell Biol., 2004, 5, 752 .

34 N. Raja, N. Devika, G. Gupta, V. L. Nayak, A. Kamal, N. Nagesh and B. Therrien, J. Organomet. Chem., 2015, 794, 104.

35 J. Q. Svejstrup, K. Christiansen, I. I. Gromova, A. H. Andersen and O. Westergaard, J. Mol. Biol., 1991, 222, 669.

36 J. A. Holden, Curr. Med. Chem.: Anti-Cancer Agents, 2001, 1(1), 1.

37 Y. Pommier, ACS Chem. Biol., 2013, 8(1), 82.

38 S. Castelli, A. Coletta, I. D’Annessa, P. Fiorani, C. Tesauro and A. Desideri, Biol. Chem., 2012, 393(11), 1327.

39 D. Strumberg, Y. Pommier, K. Paull, M. Jayaraman, P. Nagafuji and M. Cushman, J. Med. Chem., 1999, 42, 446.

40 Y. Pommier, E. Leo, H. Zhang and C. Marchand, Chem. Biol., 2010, 17(5), 421.

41 L. F. Liu, S. D. Desai, T. K. Li, Y. Mao, M. Sun and S. P. Sim, Ann. N. Y. Acad. Sci., 2000, 922, 1.

42 S. Castelli, S. Vieira, I. D’Annessa, P. Katkar, L. Musso, S. Dallavalle and A. Desideri, Arch. Biochem. Biophys., 2013, 530,7 .

43 S. Castelli, A. Campagna, O. Vassallo, C. Tesauro, P. Fiorani, P. Tagliatesta, F. Oteri, M. Falconi, H. K. Majumder and A. Desideri, Arch. Biochem. Biophys., 2009, 486(2), 103.

44 H. Ulukan and P. W. Swaan, Drugs, 2002, 62, 2039.

45 T. S. Lobana, P. Kumari, G. Hundal, R. J. Butcher, A. Castineiras and T. Akitsu, Inorg. Chim. Acta, 2013, 394, 605.

46 M. S. Inkpen, A. J. P. White, T. Albrecht and N. J. Long, Chem. Commun., 2013, 49, 5663.

47 G. A. Sheldrick, Acta Crystallogr., Sect. A: Found. Crystallogr., 2008, 64, 112.

48 G. A. Sheldrick, Crystal structure refinement with SHELXL, Acta Crystallogr., Sect. C: Struct. Chem., 2015, 71, 3.

49 V. Vichai and K. Kirtikara, Nat. Protoc., 2006, 1, 1112.

50 H. Hong-Liang, L. Zheng-Zheng, L. Zhen-Hua, Y. Jun-Hua and L. Yun-Jun, Eur. J. Med. Chem., 2011, 46, 3282.

51 J. O’Brien, I. Wilson, T. Orton and F. Pognan, Eur. J. Biochem., 2000, 267, 5421. 